\title{
Perception of Forensic Odontology and its Practice among the Local Dentists of an Institution
}

\author{
Shivani Bhakhri ${ }^{{ }^{*}}$, Arshroop Kaur ${ }^{1}$, Karanprakash Singh ${ }^{2}$, Mahijeet Singh Puri ${ }^{2}$, Navgeet Puri $^{1}$ and Chitra Anandani ${ }^{3}$ \\ ${ }^{1}$ Department of Orthodontics, Luxmi Bai Institute of Dental Sciences and Hospital, India \\ ${ }^{2}$ Department of Public Health dentistry, Luxmi Bai Institute of Dental Sciences and Hospital, India \\ ${ }^{3}$ Department of Oral Pathology \& Microbiology, Luxmi Bai Institute of Dental Sciences and Hospital, India
}

*Corresponding author: Shivani Bhakhri, Intern, Luxmi Bai Institute of Dental Sciences and Hospital, Sirhind Road, Patiala-147001, Punjab, India, Tel: 919878624131; E-mail: shivanibhakhri@gmail.com

Received date: March 21, 2017; Accepted date: April 10, 2017; Published date: April 14, 2017

Copyright: (C) 2017 Bhakri S, et al. This is an open-access article distributed under the terms of the Creative Commons Attribution License, which permits unrestricted use, distribution, and reproduction in any medium, provided the original author and source are credited.

\begin{abstract}
Forensic odontology has developed as one of the admired and significant branches of forensic sciences. Therefore, the main intention of the study is to scrutinize the perception of forensic odontology and its practice among the dental practitioners. A cross-sectional study was conducted among 152 subjects including interns, BDS staff and MDS staff through a questionnaire proforma. The proforma consisting of 16 questions was prepared on the topic of forensic odontology. The student's t-test and ANOVA test were used as tests of significance for data assessment and the statistical significance was set at $p<0.05$. In this study, $85 \%$ of dental practitioners maintain dental records and the most frequently used method among all is to record patient details (25.50\%) which is followed by dental history (21.20\%). Dental hard tissue (48.5\%) and DNA (41.4\%) examination were considered the ideal method of identification in case of mass disasters. Overall understanding of the theme seemed to be superior in senior faculty. This study shows that although there is an adequate knowledge and good attitude among dental practitioners regarding forensic odontology, yet they need more exposure from practical point of view.
\end{abstract}

Keywords: Dental practitioners; Forensic odontology; Perception; Practice

\section{Introduction}

The term "forensic" is derived from the latin word "forensis" that means a place where legal affairs are conversed [1]. Forensic odontology can be defined as the branch of dentistry that addresses the proper handling and examination of dental evidence and also the evaluation and presentation of dental findings in the interests of justice.

The key forte of forensic odontology is the identification of human remnants through dental records, determination of age and gender of the living or deceased and to give evidence as a gourmet witness in the court for the appearance of dental evidence [2].

Additionally, it is also useful in cases of criminal, marital and social disputes and in the identification of individuals missing for a long duration [3]. The four foremost areas of interest of forensic dentistry are: dental identification, bite marks investigation, cheiloscopy (study of lip prints) and rugoscopy (study of palatal rugae patterns) [4].

Dental identification plays a significant task in identification of human remains when postmortem alterations such as traumatic tissue injury occur to such an extent that finger prints cannot be recorded [5]. Nowadays, natural and man-made catastrophes are occurring more frequently in India. Under these conditions, the bodies of the sufferers become mutilated beyond recognition, and so dental records can be a useful tool in the identification of such cases.

However, the experience among dentists regarding forensic sciences is still insufficient in India [6]. Therefore, the present study was performed to appraise the perception of forensic odontology and its practice among dental professionals.

\section{Methodology}

\section{Study population}

A cross-sectional study was conducted to determine the knowledge, attitude and practice regarding forensic odontology among the students and faculty of Luxmi Bai Institute of Dental Sciences \& Hospital, Patiala, India. An official permission from the Head of the Institute was taken to conduct the study.

Those who were willing to contribute in the survey were requested to fill in the consent form and complete the questionnaire. Around 60 faculty members of which 25 were MDS and 35 were BDS. The number of interns in the institute was 118 .

\section{Criteria of selection}

Inclusion criteria- All the interns, BDS staff and MDS staff present during the study period were included in the study.

Exclusion criteria- The participants who did not respond and were not available on the day of visit were excluded.

A total of 165 dentists present during the study were given the questionnaire and 152 of them retorted with the complete proforma.

\section{Questionnaire}

A pilot assessment was done on 10 dental practitioners to ensure the precision and appropriateness of the questions. Most of the 
Page 2 of 4

contributors found the questionnaire to be uncomplicated and satisfactory.

The proforma consisting of 16 questions was prepared to ensure the command and approach towards forensic odontology among dental practitioners. The questions included the importance of dental records, detection of child abuse cases, dental age assessment, recognition of an individual, bite marks assessment, attitude of the practitioner towards maintenance of dental records. All the participants were asked to respond to each item. Confidentiality and ambiguity of the participants were guaranteed.

\section{Data analysis}

Data was recorded on Microsoft excel software for statistical analysis. Each accurate response was given a score of ' 1 ' and inaccurate answer was assigned a score of ' 0 '. All the scores were added to attain a total score. Data was evaluated by means of SPSS version 16 (SPSS, Chicago, IL, USA). The student's t-test and ANOVA test were used as tests of significance for data estimation. The statistical significance was standard at $\mathrm{p}<0.05$.

\section{Results}

The study sample composed of 152 participants including interns (102), BDS (27) and MDS (23). The age of the participants ranged from 20 to 51 years with a mean age of $28 \pm 5.648$. Female participants (98) were more in number as compared to male participants (54).

\begin{tabular}{|l|l|}
\hline Questions & Response \\
\hline Are you aware of the bite marks identification? & $71.40 \%$ \\
\hline Are you aware of lip prints identification? & $88.10 \%$ \\
\hline Are you aware of rugae pattern identification? & $78.80 \%$ \\
\hline Do you maintain dental records in clinic? & $85 \%$ \\
\hline Are you aware that you can testify as an expert witness in the court to present forensic dental evidence? & $57.40 \%$ \\
\hline Can you estimate the age and gender of deceased in the mass disaster? & $59.40 \%$ \\
\hline Do you think your present knowledge level regarding forensic dentistry is adequate? & $61.30 \%$ \\
\hline Are you willing to attend any CDE programme on forensic odontology? & $85.30 \%$ \\
\hline
\end{tabular}

Table 1: Knowledge, attitude and practices pertaining to forensic dentistry.

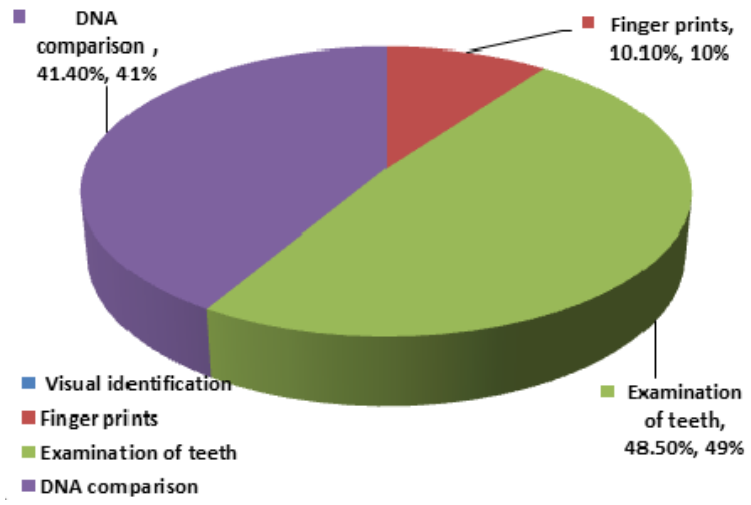

Figure 1: Showing most accurate and sensitive method to identify an individual in mass disaster.

The study showed considerable knowledge among the participants as illustrated in Table 1. Dental records (48.5\%) were considered to be the accurate method of identification in mass disaster cases followed by identification via DNA (41.4\%) and finger prints (10.1\%). None of the participant mentioned about visual identification method as illustrated in Figure 1. Similarly for the assessment of age, teeth were deemed as the ideal tool for identification $(56.2 \%)$ as mentioned in Figure 2.

In this study various methods were used by the respondents to maintain dental records, but the most frequently used one was recording patient's details $(25.50 \%)$ which was followed by dental history $(21.20 \%)$ and the least frequently used method was performing investigation tests $(6.30 \%)$ as referred in Figure 3.

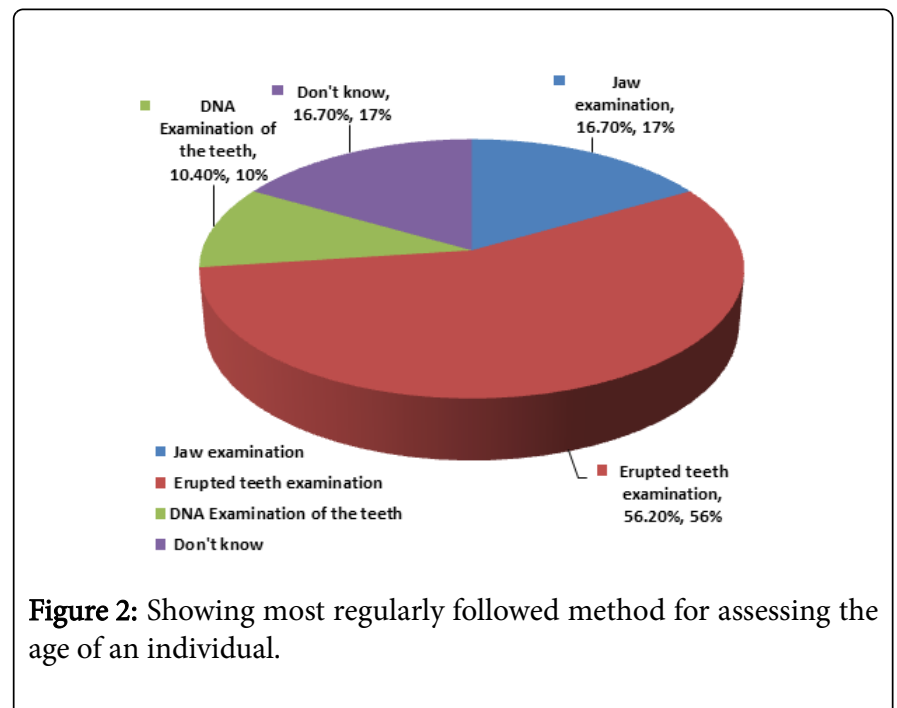


Page 3 of 4

Figure 4 reveals that majority of participants i.e. $28.40 \%$ considered that the internet is most frequently used source of upgrading knowledge about forensic odontology and a small number of participants gathered the information from CDE programmes.

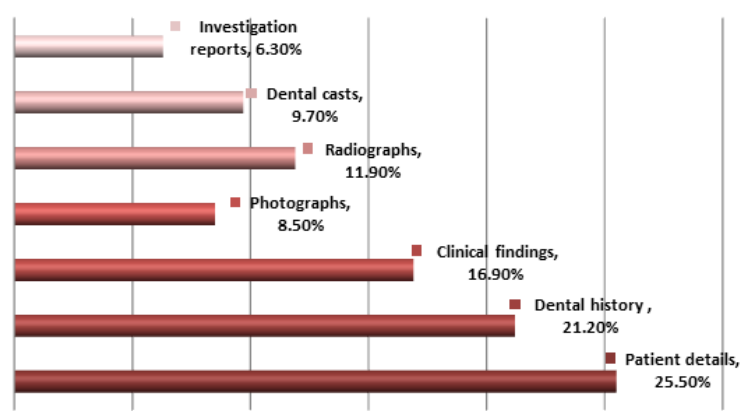

Figure 3: Showing most regularly followed method to maintain dental records.

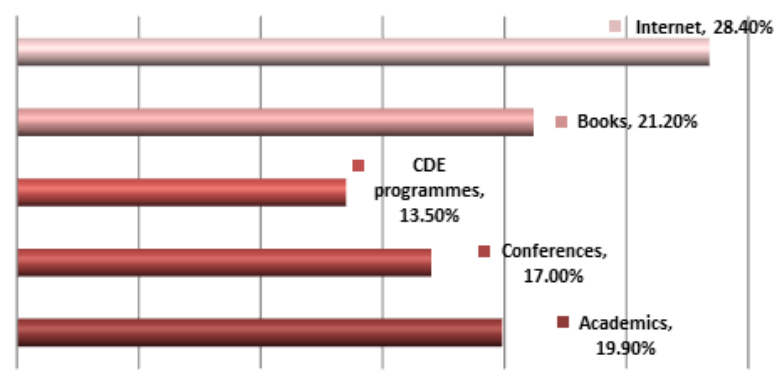

Figure 4: Showing different methods of upgrading knowledge about forensic dentistry.

\begin{tabular}{|l|l|l|l|l|}
\hline Gender & No & Mean & SD & p-value \\
\hline Males & 54 & 8.63 & 1.339 & \multirow{2}{*}{0.445} \\
\cline { 1 - 4 } Females & 98 & 8.34 & 1.522 & \\
\hline
\end{tabular}

Table 2: Showing awareness of forensic odontology according to gender.

\begin{tabular}{|c|c|c|c|c|c|c|}
\hline $\begin{array}{l}\text { Age } \\
\text { groups }\end{array}$ & No & Mean & SD & $\begin{array}{l}\text { Std. } \\
\text { Error }\end{array}$ & F-value & $p$-value \\
\hline $\begin{array}{l}20-30 \\
\text { years }\end{array}$ & 118 & 8.35 & 1.449 & 0.13 & \multirow{4}{*}{5.498} & \multirow{4}{*}{0.005} \\
\hline $\begin{array}{l}31-40 \\
\text { years }\end{array}$ & 19 & 8 & 1.599 & 0.367 & & \\
\hline $\begin{array}{ll}\geq & 41 \\
\text { years }\end{array}$ & 15 & 9.5 & 1.033 & 0.258 & & \\
\hline Total & 152 & 8.43 & 1.473 & 0.116 & & \\
\hline
\end{tabular}

Table 3: Showing awareness of forensic odontology according to age.
Overall, the findings pointed out that male $(8.63 \pm 1.339)$ had better awareness of forensic odontology than females $(8.34 \pm 1.522)$ (Table 2). The age group of ( 31 years to 40 years) showed minimum scores regarding awareness of forensic odontology compared to other groups and the results were significant ( $\mathrm{p}=0.005)$ (Table 3). According to the qualification, MDS faculty had superior understanding of the topic followed by interns and BDS faculty as represented in Table 4 .

\begin{tabular}{|l|l|l|l|l|l|l|}
\hline Qualification & No & Mean & SD & $\begin{array}{l}\text { Std. } \\
\text { Error }\end{array}$ & F-value & p-value \\
\hline Interns & 102 & 8.39 & 1.419 & 0.132 & & \\
\cline { 1 - 2 } & 27 & 8.35 & 1.848 & 0.403 & \multirow{2}{*}{0.47} & \multirow{2}{*}{0.626} \\
\cline { 1 - 5 } MDS & 23 & 8.71 & 1.402 & 0.292 & & \\
\hline Total & 152 & 8.43 & 1.473 & 0.116 & & \\
\hline
\end{tabular}

Table 4: Showing awareness of forensic odontology according to qualification.

\section{Discussion}

Today, the rapid development of forensic medicine is incomprehensible without forensic odontology which is a highly specialized branch of science that deals with the legal aspects of dentistry. Forensic dental sciences have been established over many years as the widely acceptable method of ascertaining dental evidence for identification of victims and suspects in mass disaster, abuse and other criminal cases [7].

Most trustworthy guide in the process of identification is age assessment by means of teeth. Teeth, periodontal tissues and normal anatomical features are assessed in comparative dental identification [8]. Moreover, Forensic dental investigation mainly depends upon the availability of antemortem and postmortem records [9]. Therefore maintenance of complete dental records is very important.

In the present study, $85 \%$ of the dental practitioners maintain the dental records while the study conducted in Pune by Namrata et al. found that $70 \%$ of dental practitioners usually maintain the records [10]. However, some studies have showed that only few of the dentists maintain dental records in their practice $[8,11]$.

Furthermore, the most regularly followed method to maintain dental records in this study is via documenting patient's essential details $(25.50 \%)$ and the least followed method is to maintain investigation reports as followed by $6.30 \%$ of dentists.

The dental tissues have the ability to withstand environmental assaults and still retain some of its original structure which attributes to the significance of forensic odontology. This makes teeth an excellent and an accurate source for DNA material [11]. Similarly in this study DNA comparison was amongst the most accurate and sensitive method to identify an individual in mass disaster (41\%). This was in contrast to the study conducted by Namrata et al who observed that $65 \%$ of dentists were in favour of DNA examination as the preferred method of identification [10].

The dental records are also maintained as consumer court evidence and for dental insurances [9]. The current study shows that $57.4 \%$ of dentists were aware of the fact that they can testify as an expert witness in the court to present forensic dental evidence. This was in contradiction to the studies conducted by Preethi et al. [12] and 
Namrata et al. [10] wherein nearly one-third and $65 \%$ of the respondents, respectively, were unaware of their ability to witness forensic dental evidence. Above all, a few were not willing to testify even if they were called upon.

Other important aspect of forensic odontology is bite- mark analysis. Bite marks can be easily found in food stuffs such as butter products, chocolates, cheese etc. Each dentition, including the number of teeth, their position, occlusion and the restoration are unique for each individual [11]. Therefore, these marks provide a kind of dental identification $[13,14]$ In the current study, $71.4 \%$ of the dentists are aware of bite marks identification while in the study conducted by Preethi et al., $82 \%$ of dentists knew the significance of bite marks pattern of teeth [11].

In cases of mass disaster, the identification of large number of causalities is complex and a difficult process. A forensic odontologist plays an important role in the identification of the age and gender of the deceased individuals [15]. 59.4\% of the dentists in our study are cognizant of estimation of the age and gender of deceased in any major catastrophe, which is in accordance with the study conducted by Preethi et al. [11].

Examination of lip prints, known as cheiloscopy, is also one of the adjuvant technique in identification [16]. Lip prints are also as unique as finger prints of an individual, therefore it can also be used as a supplementary tool to verify the suspect in a criminal act [17]. The present data noticed that $88 \%$ of dentists were aware of lip prints identification and the figures are a little higher than the study conducted by Nagarajappa et al. where $71.4 \%$ of dentists were aware of this facet [18].

Overall, we observed that the study participants were lacking confidence in giving expertise in this subject. This might be due to factors such as unavailability of fully operational laboratories of forensic odontology. Also forensic science is not included as an integral part of the academic prospectus. The study is conducted in a single institution which is one of the main limitations of the study.

\section{Conclusion}

The current study revealed that male participants had additional awareness of the topic than females. It was also found that the command and perception of the dentists towards this subject is satisfactory. However they are somehow lagging behind practically. Therefore, regular courses on forensic dentistry must be introduced by dental council and other dental organizations to train in the branch of forensic odontology for the betterment of human race.

\section{References}

1. Puerini SJ (2005) Forensic odontology and the postmortem identification process. Med Health R I 88: 308-309.

2. Presecki Z, Brkic H, Primorac D, Drmic I (2000) Methods of preparing the tooth from DNA isolation. Acta Stomatol Croat 34:21-24.

3. Sheikh S, Pallagatti S, Singla I, Gupta R (2011) Postmortem dental identification in the absence of anti-mortem records-A review. J Forensic Res 2:132.

4. Debnath N, Gupta R, Nongthomban RS, Chandran P (2016) Forensic odontology. J Med Soc 30: 20-23.

5. Avon S (2004) Forensic Odontology: The roles and responsibilities of the dentist. Can Dent Assoc 70: 453-458.

6. Shanbhag VKL (2016) Significance of dental records in personal identification in forensic sciences. J Forensic Sci Med 2: 39-43.

7. Prasad S, Sujatha G, Sivakumar G, Muruganandhan J (2012) Forensic Dentistry-What a dentist should know. Indian J Multidiscip Dent 2: 443-447.

8. Shamim T (2006) Human bite marks: The tool marks of the oral cavity. JIAFM 28: 52-54.

9. Charangowda BK (2010) Dental records: An overview. J Forensic Dent Sci 2: 5-10.

10. Harchandani N, Marathe S, Hebbale M, Ul Nisa S, Hiremutt D (2014) Awareness of forensic odontology among general dental practitioners in Pune - A cross-sectional study. J Adv Med Dent Scie Res 2: 10-16.

11. Preethi S, Einstein A, Sivapathasundharam B (2011) Awareness of forensic odontology among dental practitioners in Chennai: a knowledge, attitude, practice study. J Forensic Dent Sci 3: 63-66.

12. Pretty IA, Sweet D (2001) A look at forensic dentistry-Part 1: The role of teeth in determination of human identity. Br Dent J 190: 359-366.

13. Rao DS, Ali IM, Annigeri RG (2016) Bitemarks - A review. J Dent Res Rev 3: 31-35.

14. Daniel MJ, Pazhani A (2015) Accuracy of bite mark analysis from food substances: A comparative study. J Forensic Dent Sci 7: 222-226.

15. Adebisi SS (2009) Forensic anthropology in perspective: The current trend. Internet J Forensic Sci 4: 1

16. Thomas CJ, Van Wyk CW (1988) The palatal rugae in an identification. J Forensic Odontostomatol 6: 21-27.

17. Sultana Q, Shariff MH, Asif M, Avadhani R (2014) Cheiloscopy: A scientific approach for personal identification. Int J Anat Res 2: 668-672.

18. Nagarajappa R, Aapaliya P, Sharda AJ, Asawa K, Tak M, et al. (2013) Teledentistry: Knowledge and attitudes among dentists in Udaipur, India. Oral Health Dent Manag 12: 502. 